$\xi=-$ 圆

\title{
Gas Emission of Palm Oil Waste Bricks During Firing Process at Different Heating Rates
}

\author{
Noor Amira Sarani ${ }^{1}$, Aeslina Abdul Kadir ${ }^{2 *}$, Hamidah Syd Othman ${ }^{3}$ \\ ${ }^{1,2,3}$ Department of Water and Environmental Engineering, \\ Faculty of Civil and Environmental Engineering, \\ Universiti Tun Hussein Onn Malaysia, \\ 86400 Batu Pahat, Johor, Malaysia \\ *Corresponding author E-mail: aeslina@uthm.edu.my
}

\begin{abstract}
The demand for brick materials is expected to increase rapidly. However, pollutant emission during the firing process becomes a threat to the human and environment. Therefore, this study is focusing on the release of pollutant gasses during firing manufactured bricks. The bricks were incorporated with $5 \%$ of palm oil waste (palm kernel shell and empty fruit bunches) and fired at different heating rates: $1^{\circ} \mathrm{C} / \mathrm{min}, 3^{\circ} \mathrm{C} / \mathrm{min}$ and $5^{\circ} \mathrm{C} / \mathrm{min}$. All samples were fired until it reached $1050^{\circ} \mathrm{C}$ and retained for 2 hours soaking time. The gas emission measured during firing process includes carbon monoxide $(\mathrm{CO})$, carbon dioxide $\left(\mathrm{CO}_{2}\right)$, nitrogen oxide $(\mathrm{NO})$ and sulfur dioxide $\left(\mathrm{SO}_{2}\right)$. The results of estimated total emission (ETE) of gasses were compared to control bricks and palm oil waste brick. The result obtained has shown that increased heating rates cause decreased in gas emission, especially for $\mathrm{CO}_{2}$ and $\mathrm{CO}$. Therefore, this study determined that pollutant gasses are least minimal at high heating rates $\left(5^{\circ} \mathrm{C} / \mathrm{min}\right)$. As a conclusion, several pollutant gasses did not comply with the federal Clean Air Act's National Ambient Air Quality Standard (NAAQS) set by Environmental Protection Agency.
\end{abstract}

Keywords: Empty Fruit Bunch; Fired Clay Brick; Gas Emission, Palm Kernel Shell

\section{Introduction}

Brick is an essential building material in the construction field. According to [1], approximately $60 \%$ of bricks were used in a new housing project, $20 \%$ for commercial buildings and $20 \%$ for repair and maintenance. Undoubtedly, brick industry has grown rapidly all over the world. As a result of these activities, some pollutant gasses are released from brick-making industries. In the review of atmospheric emission metrics in clay brick firing technologies, Akinshipe and Kornelius identify brick industries is one of major sources of greenhouse gas emission in the world [2]. The pollutant gasses may derive during firing process in terms of carbon dioxides, nitrogen oxides, sulphur oxides, inorganic fluorine and chlorine compounds as well as organic compounds [3-5]. The negative effects of releasing harmful gasses are not only a threat to the environment but also have an adverse effect on human health Detailed study by [6] showed that fuel released from firing activities contained dust-bound polycyclic aromatic hydrocarbons (PAHs) which may exposed to cancer risk.

During the firing process, bricks may experience several changes which are burning out of carbonaceous matter and combustible sulfur in the clay, breakdown of carbonates present in the clay and released of combined water from clay [2]. This may result in various pollutant gasses into the environment. To reduce the temperature required for sintering process, some of the researchers tend to incorporate organic additives into fired clay brick [7-9]. Due to the exothermic reaction, organic materials start to oxides and released several pollutant gasses such as carbon dioxide and carbon monoxide to the environment $[2,10]$. Therefore, the federal Clean Air Act's National Ambient Air Quality Standard (NAAQS) set by Environmental Protection Agency was established to standardize air pollutant, known as criteria pollutant into six principle which are carbon monoxide, lead, nitrogen oxides, particulate matter, ozone and sulphur dioxide [11]. This standard was established to set allowable levels of harmful pollutant in order to protect human and ecosystem health.

Meanwhile, palm oil production contributes to economic growth and industrial sector in Malaysia. However, the increase in palm oil demand has caused thousands of tons of palm oil waste generated [12]. In general, from fresh fruit bunches, only $10 \%$ of the oil can be produced while the rest generated in the form of empty fruit bunches (EFB), palm fibre (PF) and palm kernel shell (PKS) [12]. EFB consists of both chemical nor mineral components, and relying upon the handling operation on the plant. PKS are the shell segments left after the nut has been removed after crushing in the palm oil mill. PKS are a fibrous material and can be without difficulty dealt with in bulk directly from the product line to the end user [13]. Usually, waste from palm oil process will be disposed of in landfill. This will give negative impact to the land fertility and by sending those agricultural wastes to landfills [14-15]. Disposing of through incineration method is not the practical solution because those wastes will release high methane gas during incineration process that caused several environmental problems [16].

Based on previous studies, incorporation of waste products into fired clay brick is generously showing convincing result but most research only focuses on the physical and mechanical properties. However, concern about the gas emission of air pollutant during manufacturing is given minimal attention. Production of bricks results in environmental degradations due to emission of significant quantities of gaseous and particulate pollutants. According to [17], firing brick up to $1050^{\circ} \mathrm{C}$ will emit gases like 
oxides of sulphur (SOx), oxides of nitrogen (NOx), particulate pollutants and non-respirable suspended particulate matter. The results revealed that all the pollutants SOx, NOx, RSPM, NRSPM and SPM (sum of RSPM and NRSPM) were crossing the limits prescribed by National Ambient Air Quality Standards (NAAQS) during the operational phase of brick kilns. This study shows that during firing of brick that fully made of clay and soil already emit gases that do not comply with the standard.

Meanwhile, study by [18] proved that incorporating fly ash into fired clay brick is acceptable based on the result obtained. The firing temperature was used up to $1093^{\circ} \mathrm{C}\left(2000^{\circ} \mathrm{F}\right)$ during the firing brick process. The researchers conducting several testing such as mercury vapour emission, radon emission, leaching pollutants, polluting landfill, and sequestration of $\mathrm{CO}_{2}$. Based on the result shown, the mercury vapour emission is $-0.081 \mathrm{Ng} / \mathrm{h} / \mathrm{m}^{2}$ which is mean fly ash brick do not emit mercury into air but adsorb mercury from air. Testing on carbon sequestration from fly ash bricks also done and $30 \%$ decrease of $\mathrm{CO}_{2}$ that emit to the air that will bring relief to global warming. Therefore, the study concludes that fly ash brick is safer to be used as building materials.

A study by [19] revealed that incorporation of cigarette butts up to $5 \%$ releases several gases to the environment. The researchers conducted a study to evaluate the effect of different heating rates on gas emissions and properties during the firing of clay bricks and clay bricks incorporated with cigarette butts (CBs). The different heating rates used are $0.7^{\circ} \mathrm{C} \cdot \mathrm{min}^{-1}, 2^{\circ} \mathrm{C} \cdot \mathrm{min}^{-1}, 5^{\circ} \mathrm{C} \cdot \mathrm{min}^{-1}$ and $10^{\circ} \mathrm{C} \cdot \mathrm{min}^{-1}$. The parameters studied are carbon monoxide, carbon dioxide, nitrogen oxides, hydrogen cyanide and chlorine. Based on this research, the results shown was $\mathrm{CO}$ with 670.42 ppm.hr.kg-1, $\mathrm{CO}_{2}$ with 2410.80 ppm.hr.kg-1, $\mathrm{Cl}_{2}$ with 1.28 ppm.hr. $\mathrm{kg}^{-1}$, HCN with 14.83 ppm.hr. $\mathrm{kg}^{-1}$ and NO with 90.98 ppm.hr. $\mathrm{kg}^{-1}$. The researcher concludes that higher heating rates $\left(10^{\circ} \mathrm{C} \cdot \mathrm{min}^{-1}\right)$ could be resulted in substantial gas emission

Therefore, incorporating PKS and EFB in fired clay brick is an alternative way to decrease the amount of waste in the landfill and to utilize the waste to form another product. Furthermore, this research will focus on the gas emissions that will emit during manufacturing the brick with waste utilization.

\section{Materials and Methods}

The materials and method were discussed in this section in order to measure the potential gas emission from palm oil waste brick.

\subsection{Preparation of raw materials}

Clay soil was collected from Brick Company located at Yong Peng, Johor. PKS and EFB were obtained from palm oil plantation at Kluang, Johor. The raw materials were oven-dried at $105^{\circ} \mathrm{C}$ for 24 hours to remove its initial moisture. After dried, raw materials were ground and sieved to yield homogenous size. Fig 1 shows the raw materials after pass $2 \mathrm{~mm}$ sieve.

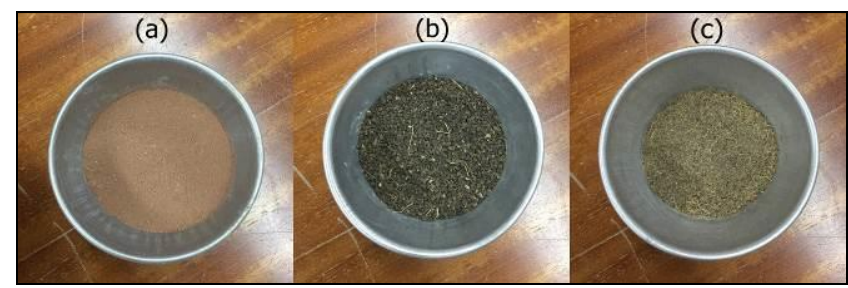

Fig. 1: Grinded of (a) clay soil, (b) PKS and (c) EFB

\subsection{Chemical characterization of raw materials}

The characterization of raw materials were conducted with X-Ray Fluorescence (XRF). This characterization to determine the chemical composition of clay soil and palm oil waste.

\subsection{Geotechnical properties of raw materials}

Geotechnical properties such as Atterberg limit test and specific gravity test were performed on clay soil and palm oil waste according to [20]. Meanwhile, optimum moisture content was determine according to [21].

\subsection{Production control of control brick and palm oil waste brick}

Three types of brick were manufactured which are control brick (CB) (0\%), empty fruit bunches brick (EFBB) and palm kernel shell brick (PKSB). Selection 5\% of palm oil wastes are based on the best physical and mechanical properties from previous study [19-20]. As mention in Table 1, the process started by mixing clay soil with predetermined water for making control brick. The mixture was then pressed using brick machine for the following size; $215 \mathrm{~mm} \times 102.5 \mathrm{~mm} \times 65 \mathrm{~mm}$. The wet brick sample was kept for 24 hours at room temperature followed by oven dried at $105^{\circ} \mathrm{C}$ for another 24 hours.

Palm oil waste brick with 5\% waste was prepared according to the previous method for making empty fruit bunches brick (EFBB) and palm kernel shell brick (PKSB).

Table 1: Ratio mixture used

\begin{tabular}{|c|c|c|c|c|c|}
\hline \multirow{2}{*}{ Mixture } & Percentage & Clay & PKS & EFB & Water \\
\cline { 2 - 6 } & $(\%)$ & $(\mathrm{g})$ & $(\mathrm{g})$ & $(\mathrm{g})$ & $(\mathrm{mL})$ \\
\hline $\begin{array}{c}\text { Control } \\
\text { brick }\end{array}$ & 0 & 2800 & 0 & 0 & 476 \\
\hline PKSB & 5 & 2710 & 90 & 0 & 518 \\
\hline EFBB & 5 & 2730 & 0 & 70 & 493 \\
\hline
\end{tabular}

\subsection{Estimated total emission of control brick and waste-} brick

The estimate total emission was determined by means of calculating the total area under the curve divided by the mass of brick (ppm/kg).

Different heating rates were applied during firing process; $1^{\circ} \mathrm{C} / \mathrm{min}, 3^{\circ} \mathrm{C} / \mathrm{min}$ and $5^{\circ} \mathrm{C} / \mathrm{min}$. The final temperature was set to $1050^{\circ} \mathrm{C}$ with 2 hours soaking time. The gas detector (YES Air Gas Detector) was equipped with sensors of carbon monoxide (CO), carbon dioxide $\left(\mathrm{CO}_{2}\right)$, nitric oxide $(\mathrm{NO})$ and sulfur dioxide $\left(\mathrm{SO}_{2}\right)$. The gas emissions were collected every 30 minutes at temperatures of $200^{\circ} \mathrm{C}, 300^{\circ} \mathrm{C}, 400^{\circ} \mathrm{C}, 500^{\circ} \mathrm{C}, 600^{\circ} \mathrm{C}, 700^{\circ} \mathrm{C}, 800^{\circ} \mathrm{C}$, $900^{\circ} \mathrm{C}, 1000^{\circ} \mathrm{C}$ and $1050^{\circ} \mathrm{C}$. The initial reading at $100^{\circ} \mathrm{C}$ should not be taken as to allow water vapour released from the brick body. At the end of the test, the emission results were employed to derive the total estimated emission of gases. Fig 2 until Fig 4 shows the colour changes during firing stage according to temperature level.

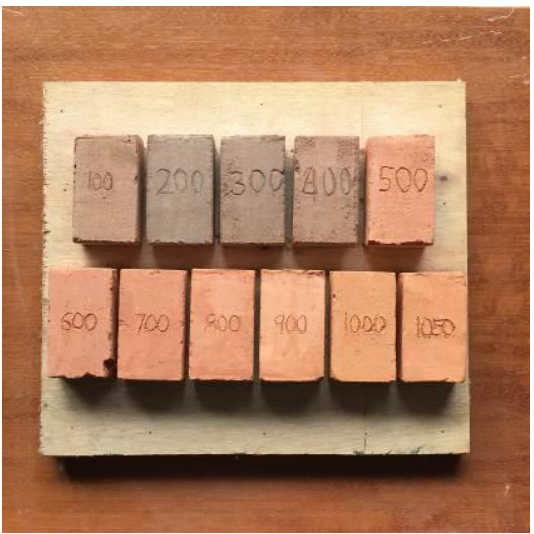

Fig. 2: Control brick after fired at different temperature 


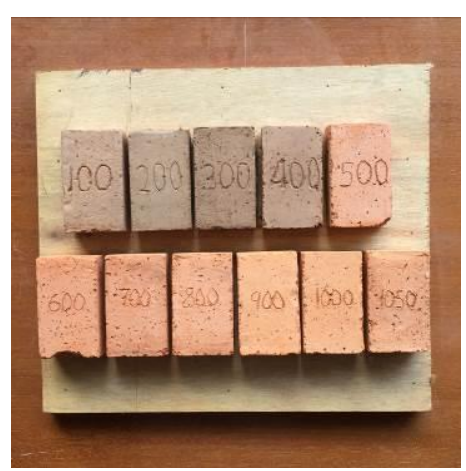

Fig. 3: PKS brick after fired at different temperature

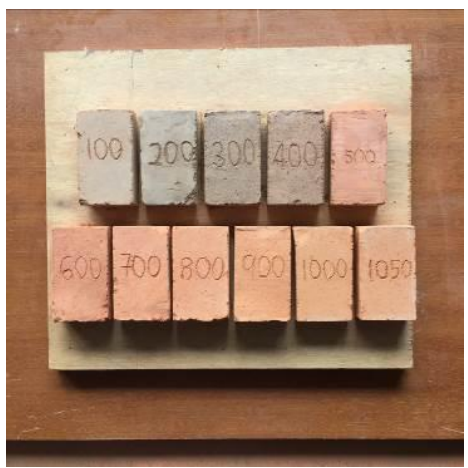

Fig. 4: EFB brick after fired at different temperature

\section{Results and discussions}

\subsection{Properties of raw materials}

Table 2 shows the chemical composition of raw materials used in the study.

From the results, clay soil is high in $\mathrm{SiO}_{2}, \mathrm{Al}_{2} \mathrm{O}_{3}$ and $\mathrm{Fe}_{2} \mathrm{O}_{3}$ with $55.70 \%, 24.40 \%$ and $4.46 \%$, respectively. Minor content was recorded as $\mathrm{MnO}, \mathrm{CaO}$ and $\mathrm{Na}_{2} \mathrm{O}$ with $0.04 \%, 0.25 \%$ and $0.79 \%$, accordingly. Similar result also shows that PKS is high in $\mathrm{SiO}_{2}$, $\mathrm{Al}_{2} \mathrm{O}_{3}$ and $\mathrm{Fe}_{2} \mathrm{O}_{3}$ with $47.10 \%, 16.19 \%$ and $10.59 \%$. Meanwhile, $\mathrm{CaO}, \mathrm{K}_{2} \mathrm{O}$ and $\mathrm{TiO}$ is the lowest chemical composition in PKS. Although the chemical composition of each POW is slightly different, due to clay flexibility, this waste is greater potential to be incorporated into fired clay brick.

Meanwhile, chemical compositions of empty fruit bunches are reported in terms of fibre content. From Table 3, lignin for EFB was comparatively low at $20 \%$. Cellulose was reported high with $38.1 \%$. Meanwhile, the content of hemicellulose of EFB is $35 \%$. Ash content in EFB found to have very low ash content with $1.5 \%$. According to several studies, incorporation high cellulose waste into fired clay brick would help to improve several physical and mechanical properties [21-22].

Table 2: Chemical composition of raw material

\begin{tabular}{|c|c|c|}
\hline \multirow{2}{*}{ Oxide content } & \multicolumn{2}{|c|}{ Concentration (\%) } \\
\cline { 2 - 3 } & Clay soil & PKS \\
\hline $\mathrm{SiO}_{2}$ & 55.70 & 47.10 \\
\hline $\mathrm{Al}_{2} \mathrm{O}_{3}$ & 24.40 & 16.19 \\
\hline $\mathrm{Na}_{2} \mathrm{O}$ & 0.30 & 0.94 \\
\hline $\mathrm{K}_{2} \mathrm{O}$ & 2.24 & 0.25 \\
\hline $\mathrm{Fe}_{2} \mathrm{O}_{3}$ & 4.46 & 10.59 \\
\hline $\mathrm{CaO}$ & 0.25 & 0.20 \\
\hline $\mathrm{MgO}$ & 1.20 & 0.93 \\
\hline $\mathrm{P}_{2} \mathrm{O}_{5}$ & n.a & 0.88 \\
\hline $\mathrm{TiO}_{2}$ & 0.94 & 0.79 \\
\hline $\mathrm{MnO}_{\mathrm{SnO}}$ & 0.04 & 1.16 \\
\hline $\mathrm{SO}_{3}$ & n.a & 1.56 \\
\hline $\mathrm{Cr}_{2} \mathrm{O}_{3}$ & n.a & 2.2 \\
\hline $\mathrm{ZnO}$ & n.a & 1.57 \\
\hline n.a $=$ not availabe & & \\
\hline
\end{tabular}

Table 3: Fibre content of EFB

\begin{tabular}{|c|c|c|c|c|}
\hline Fibre & Lignin & Cellulose & Hemicellulose & $\begin{array}{c}\text { Ash } \\
\text { content }\end{array}$ \\
\hline & $(\%)$ & $(\mathrm{g})$ & $(\mathrm{g})$ & $(\mathrm{g})$ \\
\hline EFB & 20 & 38.1 & 35 & 1.5 \\
\hline
\end{tabular}

\subsection{Geotechnical Properties of raw materials}

The Atterberg limit test was carried out to assess the physical properties of soil used in the study. According to Table 4, the soil indicates liquid limit of $52 \%$. The plasticity index was determined to be $25.2 \%$. In keeping with Unified soil classification system, the soil used in this study can be characterised as clayey silt. High plasticity of clay soil is important in the production of brick as it promotes the development of plasticity, making it easy throughout extrusion and increase homogeneity in clay bodies. Meanwhile, the specific gravity for soil determined as 2.56 .

Table 4: Classification of clay soil

\begin{tabular}{|l|c|}
\hline \multicolumn{2}{|c|}{ Table 4: Classification of clay soil } \\
\hline Soil physical properties & Results \\
\hline Liquid limit (\%) & 52.00 \\
\hline Plastic limit (\%) & 26.9 \\
\hline Degree of plasticity & 25.2 \\
\hline Type of soil & High plastic \\
\hline Specific gravity & Clayey silt \\
\hline
\end{tabular}

\subsection{Estimated Total Emission of manufactured brick}

In this investigation, the effects of different heating rates on Estimated Total Emission (ETE) were determined. According to [26], the increase in temperature during firing process will increase the release of contaminated gases into the atmosphere, while the high heating rates could reduce the release of gas. Therefore, the recorded results in Table 5 will be discussed accordingly.

Generally, ETE values for all types of brick reduced significantly with increasing of heating rates from $1^{\circ} \mathrm{C} / \mathrm{min}$ to $5^{\circ} \mathrm{C} / \mathrm{min}$ except for $\mathrm{NO}$ and $\mathrm{SO}_{2}$, which increased according to heating rates in certain bricks. As mention by [26], increasing heating rates could decrease the emission of gases, however, ETE for gases NO and $\mathrm{SO}_{2}$ is increased possibly due to incomplete combustion or measurement error.

In this study, it shows that ETE for all manufactured bricks definitely decreased with increasing heating rates. From Table 5, ETE for CB $0 \%$ is estimated to decrease from 1555.6 to $58.1 \mathrm{ppm} . \mathrm{hr} / \mathrm{kg}$ (CO), 5387.3 to $899.2 \mathrm{ppm} . \mathrm{hr} / \mathrm{kg}\left(\mathrm{CO}_{2}\right)$ and 59.7 to $2.3 \mathrm{ppm} . \mathrm{hr} / \mathrm{kg}$ $\left(\mathrm{SO}_{2}\right)$. Meanwhile, emission for $\mathrm{NO}$ was increased from 23.4 to $80.2 \mathrm{ppm} . \mathrm{hr} / \mathrm{kg}$.

Another observation for PKSB 5\% shows that ETE for all gases were decreased from 69.14 .6 to $82.9 \mathrm{ppm} . \mathrm{hr} / \mathrm{kg}(\mathrm{CO})$, and 13834.6 to $4094.5 \mathrm{ppm} . \mathrm{hr} / \mathrm{kg}\left(\mathrm{CO}_{2}\right)$ except for $\mathrm{NO}$ and $\mathrm{SO}_{2}$ which increased from 24.2 to $56 \mathrm{ppm} . \mathrm{hr} / \mathrm{kg}$ and 0.1 to $7.8 \mathrm{ppm} . \mathrm{hr} / \mathrm{kg}$, respectively.

The same trend for ETE was observed from EFBB 5\% which decreased in all gases except for NO. In case for EFBB 5\%, ETE values were decreased from 11300.3 to $95.4 \mathrm{ppm} . \mathrm{hr} / \mathrm{kg}$ (CO), 20051.3 to $5326.7 \mathrm{ppm} . \mathrm{hr} / \mathrm{kg}\left(\mathrm{CO}_{2}\right)$ and 4.9 to $2.1 \mathrm{ppm} . \mathrm{hr} / \mathrm{kg}$ $\left(\mathrm{SO}_{2}\right)$ except for $\mathrm{NO}$ with 37.3 to $57.4 \mathrm{ppm} . \mathrm{hr} / \mathrm{kg}$.

Comparable reduction patterns for ETE results were discovered for each types of fired clay brick samples. Most of the ETE values decreased substantially at $5^{\circ} \mathrm{C} / \mathrm{min}$ accompanied by $3^{\circ} \mathrm{C} / \mathrm{min}$, and $1^{\circ} \mathrm{C} / \mathrm{min}$. Nevertheless, at $1^{\circ} \mathrm{C} / \mathrm{min}$ and $3^{\circ} \mathrm{C} / \mathrm{min}$, notably higher of $\mathrm{CO}$ and $\mathrm{CO}_{2}$ were discovered for EFB and PKS bricks in comparison to control brick because of the addition of waste which offers more organic content and yields more porous brick. The development of the pore system allows the oxidation process to be extra complete, as a result ensuing in the release of higher gas emission [8]. However, considerably lower emission can be accomplished with higher heating rates $\left(5^{\circ} \mathrm{C} / \mathrm{min}\right)$. In line with the National $\mathrm{Am}$ bient Air Quality Standard (NAAQS), the gas emission from palm oil waste bricks mostly complied with the standard despite the fact that some of the gases do no longer comply with the standard. 
Table 5: Estimated Total Emission (ETE) of manufactured brick

\begin{tabular}{|c|c|c|c|c|c|}
\hline $\begin{array}{c}\text { Heating } \\
\text { rates }\end{array}$ & $\begin{array}{c}\text { Mixture } \\
\text { identification }\end{array}$ & \multicolumn{4}{|c|}{ Estimated Total Emission (ETE) (ppm.hr/kg) } \\
\hline${ }^{\circ}$ C/min & $(\%)$ & $\mathrm{CO}$ & $\mathrm{CO}_{2}$ & $\mathrm{NO}$ & $\mathrm{SO}_{2}$ \\
\hline 1 & $\mathrm{CB}$ & 1555.6 & 5387.3 & 24.3 & 59.7 \\
\hline 3 & $\mathrm{CB}$ & 71.5 & 2073.9 & 69.3 & 6.5 \\
\hline 5 & $\mathrm{CB}$ & 58.1 & 899.2 & 80.2 & 2.3 \\
\hline 1 & PKSB & 6914.6 & 13834.6 & 24.2 & 0.1 \\
\hline 3 & PKSB & 85.7 & 11368.2 & 43.7 & 7.7 \\
\hline 5 & PKSB & 82.9 & 4094.5 & 56.0 & 7.8 \\
\hline 1 & EFBB & 11300.3 & 20051.3 & 37.3 & 4.9 \\
\hline 3 & EFBB & 41.3 & 10935.3 & 41.3 & 3.0 \\
\hline 5 & EFBB & 95.4 & 5326.7 & 57.4 & 2.1 \\
\hline
\end{tabular}

\section{Conclusions}

The outcomes presented a beneficial information with regards to the control brick, EFB brick and PKS brick with different heating rates $\left(1^{\circ} \mathrm{C} / \mathrm{min}, 3^{\circ} \mathrm{C} / \mathrm{min}\right.$, and $\left.5^{\circ} \mathrm{C} / \mathrm{min}\right)$ and their effects on the estimated total emissions (ETEs). Based on the outcomes acquired, it indicates that the potential gases that emit from the EFB and PKS bricks are $\mathrm{CO}, \mathrm{CO}_{2}, \mathrm{NO}$ and $\mathrm{SO}_{2}$. The results additionally discovered that incorporation $5 \%$ of palm oil waste into fired clay brick does not emit high pollutant gasses to the surroundings. The ETE trend indicates that the higher heating rates, the lower of gas emission could be produced.

In terms of heating rates, the results indicate that rapid heating rates $\left(5^{\circ} \mathrm{C} / \mathrm{min}\right)$ significantly reduced the ETEs values. In the assessment, it was predicted that low level of water vapour within the pore system generously improved oxygen accessibilities. Under this circumstances, higher gas emission attributed to the free water vapour in the pore system, thus completely oxidise the organic content inside the brick. Incorporating of EFB and PKS in fired clay bricks is a good selection because it can reduce the amount of this waste from being disposed to the landfill where it will lead to solving and the environmental problem also land insufficiency.

\section{Acknowledgements}

The results presented in this paper are part of an ongoing postgraduate research. The authors would like to thank the Faculty of Civil and Environmental Engineering, UTHM for this study.

\section{References}

[1] Andrew B, Highley D, Lusty P, Cowley J, Cameron D, \& Rayner D (2007), Mineral Planning Factsheet. Brick Clay.

[2] Akinshipe O \& Kornelius G (2017), Chemical and Thermodynamic Processes in Clay Brick Firing Technologies and Associated Atmospheric Emissions Metrics - A Review. J Pollut Eff Cont 5(2).

[3] Cusidó JA, Cremades LV \& González M (2003), Gaseous emissions from ceramics manufactured with urban sewage sludge during firing processes. Waste Manag.23(3), 273-280.

[4] European Comission (2007), Ceramic Manufacturing Industry.

[5] Akinshipe O \& Kornelius G (2018), Quantification of atmospheric emissions and energy metrics from simulated clamp kiln technology in the clay brick industry. Environ. Pollut. 236, 580-590.

[6] Kamal A, Malik RN, Martellini T \& Cincinelli A (2014), Cance Risk Evaluation of Brick Kiln Workers Exposed to Dust Bound PAHs In Punjab Province (Pakistan). Sci. Total Environ.

[7] Butera S, Christensen TH \& Astrup TF (2014), Composition and leaching of construction and demolition waste: Inorganic elements and organic compounds, J. Hazard. Mater. 276, 302-311.

[8] Ukwatta A \& Mohajerani A (2017), Effect of Organic Content in Biosolids on the Properties of Fired-Clay Bricks Incorporated with Biosolids. J. Mater. Civ. Eng.29(7), 1-11.

[9] J de la CasaA \& Castro E (2018), Fuel savings and carbon dioxide emission reduction in a fired clay bricks production plant using olive oil wastes: A simulation study. J. Clean. Prod. 185, 230-238.
[10] Martín D, Aparicio P \& Galán E (2018), Mineral carbonation of ceramic brick at low pressure and room temperature. A simulation study for a superficial $\mathrm{CO} 2$ store using a common clay as sealing material. Appl. Clay Sci. 161, 119-126.

[11] USEPA, 'National Ambient Air Quality Standards', 2014.

[12] Abdullah N \& Sulaiman F (2013), The Oil Palm Wastes in Malaysia. in Biomass Now - Sustainable Growth and Use.

[13] Zafar S (2018), Energy Potential of Empty Fruit Bunches. BioEnergy Consult.

[14] Frazão LA (2010), Oil palm by-products as a biomass source: availability and sustainability. J. Oil Palm Res.22(2),1-4.

[15] Mohajerani A, Kadir AA \& Larobina L (2015), A Practical Proposal for Solving the World's Cigarette Butt Problem: Recycling in Fired Clay Bricks. Waste Manag. 52, 228-244.

[16] Kadir AA, Sarani NA, Abdullah MMAB, Perju MC \& Sandu AV (2017), Study on Fired Clay Bricks by Replacing Clay with Palm Oil Waste: Effects on Physical and Mechanical Properties. in IOP Conference Series: Materials Science and Engineering 209(1).

[17] Skinder BM (2014), Brick kilns: Cause of Atmospheric Pollution. J. Pollut. Eff. Control 02(02).

[18] Liu H, Banerji SK, Burkett WJ \& Vanengelenhoven J (2000), Environmental Properties of Fly Ash Bricks, in World of Coal Ash Conference, $1-18$.

[19] Kadir AA \& Mohajerani A (2105), Effect of Heating Rate on Gas Emissions and Properties of Fired Clay Bricks and Fired Clay Bricks Incorporated with Cigarette Butts. Appl. Clay Sci. 104, 269-276.

[20] BS 1377-2 (1990), Methods of Test for Soils for Civil Engineering Purposes, Part 2: Classification Tests. British Standard.

[21] BS 1377-4 (2002), Methods of test for Soils for civil engineering purposes - part 4: Compaction related tests.

[22] Kadir AA, Sarani NA \& Kadir SAA (2017), Incorporation of Palm Kernel Shell into Fired' 01017.

[23] Kadir AA, Zahari NAM \& Mardi NA (2013), Utilization of Palm Oil Waste into Fired Clay Brick. Adv. Environ. Biol. 7(12), 38263834.

[24] Sutcu M (2015), Influence of expanded vermiculite on physical properties and thermal conductivity of clay bricks', Ceram. Int. 41(2), 2819-2827.

[25] Uemura Y, Omar WN, Tsutsui T \& Yusup SB (2011), Torrefaction of oil palm wastes. Fuel, 90(8), 2585-2591.

[26] Pacheco-Torgal F, Lourenço PB, Labrincha JA, Kumar S \& P. Chindaprasirt (2015). Eco-Efficient Masonry Bricks and Blocks Design , Properties and Durability 1, Woodhead Publishing. 